\title{
Analysis of Effect of Vegetation Change on Surface Temperature in Umbulharjo Village Area, Sleman Regency Using Geographic Information System
}

\author{
Saiful Hadi $^{1 *}$, Bambang Waluyo Hadi Eko Prasetyo, ${ }^{2}$ \\ ${ }^{1}$ Magister Programme of Environmental Science, School of Postgraduate Student Diponegoro University, Semarang-Indonesia \\ ${ }^{2}$ Animal Husbandry Dept, Faculty of Engineering, Diponegoro University, Semarang-Indonesia
}

\begin{abstract}
Global Warming has increased the temperature across the hemisphere, with different sizes between regions. Land clearing for building construction is increasing in Umbulharjo Village. Plus the activity of some residents mine sand in the yard. These activities accelerate the change of vegetation cover in Umbulharjo village. Changes in vegetation cover and global warming are suspected to increase temperatures in Umbulharjo village. On the other side of Umbulharjo Village is famous for its cow's milk production. Cow's milk is produced from dairy cows that have susceptibility to temperature changes. This study attempts to analyze changes in vegetation cover and temperature changes in Umbulharjo Village using Geographic Information System method.
\end{abstract}

Keywords: Change of vegetation cover, temperature change, dairy cattle, geographic information system.

\section{Introduction}

Mount Merapi slope is a potential area for dairy farming. Since 1980 dairy farming was held in Umbulharjo village, Sleman district. Dairy cows that are raised are Fries Holstein dairy cows. It is a species that originates from subtropical regions rather than native to Indonesia. Indonesia is a tropical region where temperatures are hotter than subtropics. At this time the production of Fies Holstein cattle milk in Indonesia is only one-third of the production of cow's milk from sub-tropical countries. To achieve production equivalent to those in the subtropical region would be difficult. What needs to be done is to maintain existing production. Maintaining existing production ensures nutritional security for Indonesians. Merapi eruption in 2010 has reduced vegetation cover in Umbulharjo village. The possibility of reduced vegetation cover, there is also an increase in temperature.

Umbulharjo village is located about $10 \mathrm{Km}$ west of District Cangkringan and $18 \mathrm{Km}$ east of the capital Sleman. The total area of the village as a whole is 826 Ha. Viewed from the topography, Umbulharjo's altitude is at $500 \mathrm{~m}$ up to $1000 \mathrm{~m}$ asl with an average rainfall of $2,225 \mathrm{~mm} / \mathrm{yr}$, and the average temperature per year is 19-24 ${ }^{\circ} \mathrm{C}$. Umbulharjo Village through Opak River in the east and Yellow river in the west.located at coordinates with an area of 800 ha. The area has a height of places from $600 \mathrm{mdpl}$ to $1100 \mathrm{mdpl}$. Regency of Merapi in the north, Kepuharjo village, Cangkringan subdistrict, south of Wukirsari village, Cangkringan subdistrict, and Hargobinangun village in the west, Pakem sub district.
Climate conditions in most areas of Umbulharjo Village include wet tropics with $22 \mathrm{~mm}$ average rainfall, maximum wind speed of 5.92 knots and a minimum of 1.3 knots, and a minimum of 1.3 knots, the highest relative humidity of $95.1 \%$ and the lowest $49.2 \%$ while the highest air temperature $31^{\circ} \mathrm{C}$ and the lowest $19.2{ }^{\circ} \mathrm{C}$

\section{Holstein Fries Cows and stress due to rising temperatures}

Dairy farming in Indonesia has been started since the 19th century, ie since the arrival of dairy cows from Australia conducted by the Dutch government. In those days dairy cows were managed by a company that aims to provide milk consumption for Europeans [1]. Dairy cattle cultivated in Indonesia are mostly of the FH (Fries Holland) and peranakan types [2].

Fries Holland's dairy cow at its original place is fond of or accustomed to climate temperatures between 13 to 25 degrees Celsius. When Holstein cows undergo high temperature treatment, high humidity, and exposure to direct sunlight, the cow is potentially exposed to stress. Stress on dairy cattle affects physiological function in the body and the tip can decrease milk production [3]. Hot temperatures have the potential to decrease the appetite of cow consumption, when the temperature reaches 40.6 ${ }^{\circ} \mathrm{C}$ the consumption of food in Fries Holland cattle will be halted [4].

\footnotetext{
*Corresponding author: saifulhadiundip@gmail.com
} 
Development of dairy cattle (imports and derivatives) in the highlands shows better productivity performance results than in the lowlands. Agroecosystem, availability of feed and appropriate maintenance management, will support the productivity of dairy cows [5]

Fries Holland type cattle due to rising temperatures cause physiological changes with decreased appetite symptoms, plenty of drinking, cell anabolism decreases but cellular catabolism rises, hormone concentrations in the body decreases, increased evaporation, rising body temperature, respiratory rate, and heart rate [6]. Dairy cows will also experience behavioral changes [7].

Higher environmental temperatures can decrease feed consumption in the whole nation of dairy cows. The consumption of rations began to decrease when the ambient temperature rose from $24-25{ }^{\circ} \mathrm{C}$ in Holland Fries cattle, $26-29^{\circ} \mathrm{C}$ in Jersey cattle, above $29.5^{\circ} \mathrm{C}$ in Swiss Brown cattle, and $32-35{ }^{\circ} \mathrm{C}$ in Brahman. Consumption of livestock Holland Fries cattle lactation will decrease by $20 \%$ at $32{ }^{\circ} \mathrm{C}$ and will stop eating at temperatures above $40{ }^{\circ} \mathrm{C}$ [8].

Dairy cows can live comfortably and produce optimally when internal and external factors are within normal limits to suit their life needs. Environmental temperature is one of the external factors that can affect the comfort and productivity of dairy cattle. Environmental thermal stress on dairy cattle is one of the main problems as it can cause economic losses due to decreased productivity [9].

There is a correlation between temperature changes with the quality of milk content, milk fat content, and protein content in milk and can be seen in the graph below [10].

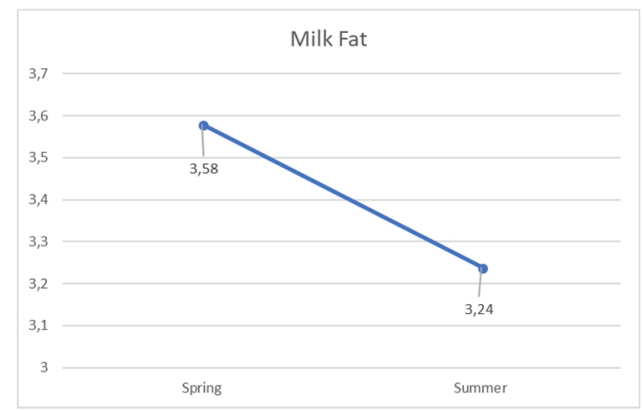

Fig. 1. Relationship between milk fat levels and seasonal differences.

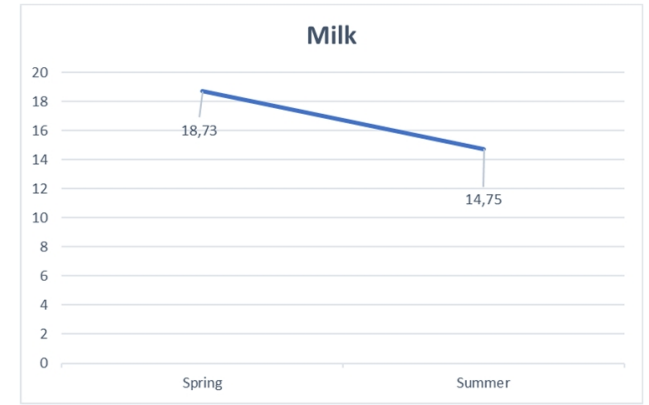

Fig. 2. Relationship between milk content levels and seasonal differences.

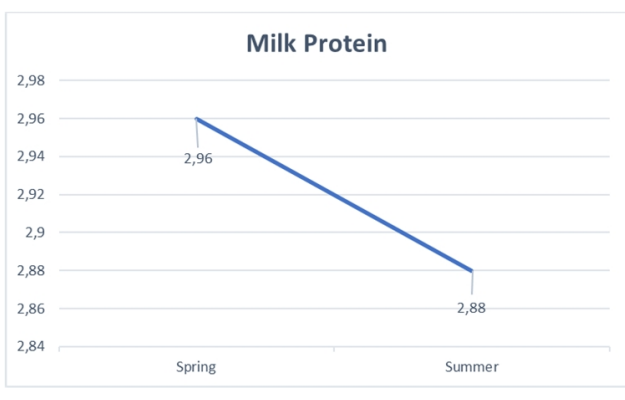

Fig. 3. Relationship between milk content levels and seasonal differences.

\section{Vegetation and temperature increase}

Forest-forming vegetation is a natural component capable of controlling the climate through controlling fluctuations or changes in surrounding climate elements such as temperature, humidity, wind and precipitation, and determining local climatic conditions and microclimate [11].

\section{Geographic Information System}

Remote sensing digital imagery is an image depicting the surface (or near surface) appearance of the earth obtained through the process of recording reflectance, emittance, or backscatter electromagnetic waves with an optical-electronic sensor mounted on a vehicle, whether it be the rides of dimenara, aircraft and spacecraft [12].

Geographic Information System is a computer system to enter, analyze spatial data in a database that is used for decision making [13] .

GIS is a collaborative arrangement of hardware, software, and data components, and can use a system of storing, processing, and analyzing data in harmony, so as to obtain data related to spatial aspects. GIS is a spatial and non-spatial data management using a computer with three basic characteristics, namely: (i) having an actual problem; (ii) is a special feature of a coordinate; and (iii) relate to time [14].

GIS is a set of computers, software, geographic and human characteristics designed to obtain, store, update, engineer, analyze, and display all forms of geo-reference information [15].

\subsection{NDVI}

NDVI (Normalized Difference Vegetation Index) is an image calculation used to determine the excellent greenish level as the beginning of the division of the vegetation area. NDVI can show parameters related to parameters, among others: green foliage biomass, green foliage area which is an estimated value for vegetation division. Choice 2 Band must be done with various considerations, namely reflection of light by the object (Reflectance), absorption of light by the object (Absorptance) and lightness by the object (Transmittance). The maximum reflection on vegetation occurs at Near Infrared wavelengths. The maximum reflection is caused by the leaf structure (mesophyll) 
which can increase the reflection of Near Infrared waves. Maximum absorption occurs at Visible Red wavelength. Absorption is caused by a green leaf substance (Chlorophyll) [16].

The NDVI equation is the result of a reduction between Near Infrared minus Visible Red divided by Near Infrared addition plus Visible Red, before performing the equation first the input of the band must be corrected radiometrically.

\subsection{Land Surface Temperature}

Land Surface Temperature (LST) can provide important information about the physical properties of surfaces that play an important role in the process associated with changes in surface temperature in the surrounding environment [17].

Determination of the surface temperature of this land by observing the change of vegetation cover seen from vegetation density using vegetation index value. Vegetation can be an indicator of the dynamics of existing surface temperatures in urban areas. The more vegetation cover or with full vegetation cover the LST will be colder towards the suburbs because suburban areas have more vegetation cover, whereas the less the vegetation cover the LST gets hotter in the urban direction [18].

Another way to find out how much change and temperature depth is to record data from existing weather data recording stations. But one thing to note is the location of the stations that are far apart, and not every region there is a station (limited number), and the existence of data that is not recorded completely. Given the limitation of temperature data acquisition from the weather station, a temperature data acquisition method other than the weather station data is required, ie by using the image recorded by the thermal channel, in various recording times (multitemporal). Multitemporal information can be used to find out how much difference the difference over a given time span is displayed on the change of tone, so that it can spatially be mapped [19].

\section{Conclusions}

From this review it can be concluded that the decrease in vegetation cover can increase the temperature of the environment. Increased environmental temperature can cause stress on dairy cattle. Stress on cows can decrease the productivity and quality of milk. The use of geographic information systems can make it easier for dairy farmers to estimate environmental conditions. Adaptation and mitigation strategies will be more easily formulated if the data held more accurately. By maintaining the extent of vegetation, the vegetation can always play a role in reducing carbon in the air. This research method can contribute to future strategies in low carbon development.

\section{References}

[1] Sudono, A., Fina, and Budi. Beternak Sapi Perah secara Intensif. Penerbit Agromedia Pustaka. Depok. (2002).

[2] Danuwidjaya, D., Pemantapan Usaha Persusuan Dengan Usaha Koperasi, Pusat Penelitian dan Pengembangan Ternak, Ciawi, Bogor, (1980).

[3] Yani, A., and Purwanto, B. P. Pengaruh Iklim Mikro terhadap Respons Fisiologis Sapi Peranakan Fries Holland dan Modifikasi Lingkungan. Media Peternakan. 29(56), 35-46. (2006).

[4] Hafez, E. S. Adaptation of Domestic Animals. Philadelphia. (1968).

[5] Ratnawati et all, D. (n.d.). Kinerja Produktivitas Sapi Perah Impor dan Hasil Turunannya di Jawa Timur : Studi Kasus di Dataran Rendah dan Dataran Tinggi Pasuruan. Semiloka Nasional Prospek Industri Sapi Perah Menuju Perdagangan Bebas. (2020).

[6] McNeilly., Reproduction, fertility, and development. CSIRO Publishing, 583-590, (2001).

[7] Philips C., Cattle Behaviour and Welfare. Blackwell Publishing. Malden, USA, (2002).

[8] Sudono., Beternak Sapi Perah Secara Intensif, AgroMedia Pustaka, Bogor, (2003).

[9] St-Pierre NR, Cobanov B, S. G., Economic losses from heat stress by US livestock industries. J Dairy Sci, 86:E52-E77, (2003).

[10] Bouraoui, R. Lahmar, M. Majdoub, J. Djemali, M. Belyea, R., The relationship of temperaturehumidity index with milk production of dairy cows in a Mediterranean climate. Anim. Res 51. 479491, (2002).

[11] Indriyanto., Ekologi Hutan (Cetakan I.), Bumi Aksara, Jakarta, (2006).

[12] Aronoff, S.)., Geographic Information System : A Management Perspective. Otawa. Canada, (1993).

[13] Purwadhi, \& Hardiyanti, S., Interpretasi Citra Digital, PT. Grasindo, Jakarta, (2001).

[14] ESRI., Understanding GIS: The ArcInfo Method,Environtment System Research InstituteInc. Redlands. USA, (1990).

[15] As-syakur, A. R. And I. W. S. Adnyana., Analisis Indeks Vegetasi Menggunakan Citra Alos/Avnir-2 dan Sistem Informasi Geografi (SIG) untuk Evaluasi Tata Ruang Denpasar. Jurnal Bumi Lestari 9:1-11, (2009).

[16] Dousset, B. Gourmelon, F. Mauri, E. Application of satellite Remote Sensing for Urban Risk Analysis: a case study of the 2003 extreme heat wave in Paris. Urban Remote Sensing Joint Event, (2007).

[17] Weng, Q. Lu, D. Schubring, J., Estimation of land surface temperature-vegetation abundance relationship for urban heat island studies. Remote Sensing of Environment 89. 467-483, (2004).

[18] M. Prakash, R. Rankin, V. T. Tikhoncuk. Precipitation and nonlinear effects in geomagneticfield line resonances. Journal of Geophysical Research : Space Physic/ Volume 108, (2003). 